\title{
Kemampuan Berpikir Tingkat Tinggi Dalam Pemanfaatan YouTube Sebagai Media Pembelajaran Bahasa Indonesia
}

\author{
*Brillianing' Pratiwi ${ }^{1}$, Kusnindyah Puspito Hapsari ${ }^{2}$
}

1,2 Prodi Pendidikan bahasa dan Sastra Indonesia, FKIP, Universitas Terbuka, Indonesia

\section{A R T I C L E I N F O}

Article history:

1 Maret 2020 Received in revised form

30 Maret 2020

Accepted 11 April 2020

Available online 15

Mei 2020

\section{Kata Kunci:}

Youtube,

Bahasa Indonesia,

berfikir tingkat tinggi.

Keywords:

Youtube,

Indonesian language,

high order thinking.

\begin{abstract}
A B S T R A K
Tujuan penelitian ini adalah memaparkan (1) pemanfaatan YouTube sebagai media pembelajaran bahasa Indonesia (2) YouTube sebagai stimulus sebelum pemberian soal High Order Thinking Skill, (3) pemanfaatan YouTube terhadap kemampuan berpikir siswa. Penelitian ini menggunakan penelitian kualitatif deskriptif dengan populasi sampel siswa kelas 1 SD Sekolah Alam Kebun Tumbuh Depok, Jawa Barat, yang berjumlah 24 siswa dan mengikuti pelajaran Bahasa Indonesia. Pengumpulan data yang dilakukan yaitu dengan metode observasi dan penggunaan tes. Instrumen yang digunakan adalah lembar observasi dan lembar soal dengan bentuk pilihan ganda. Validasi penelitian diuji dengan validitas eksternal. Teknis analisis dilakukan dengan uji pada kemampuan berpikir siswa. Hasil penelitian adalah (1) pemanfaatan YouTube efektif sebagai media pembelajaran bahasa Indonesia. (2) YouTube sebagai stimulus membantu merumuskan materi yang dijadikan dasar pertanyaan dalam konteks tertentu. (3) YouTube memudahkan siswa
\end{abstract}

mengerjakan soal mudah, sedang, dan sulit.

\section{A B S T R A C T}

The aims of this research are to explain (1) the use of YouTube as a medium of learning Indonesian language (2) YouTube as a stimulus before giving a High Order Thinking Skill, (3) the use of YouTube to support students thinking ability. This study uses descriptive qualitative research with the sample is first grade Elementary School students who take Indonesian language lessons. Data collection by observation methods and the use of tests. The instruments used were observation sheets and questions in a multiple choice form. Research validation was tested with external validity. Data were analyzed using the test of students thinking ability. The results of the study are (1) Effective use of YouTube as a medium for learning Indonesian. (2) YouTube as a stimulus. 3) YouTube makes students to work on easy, medium, and difficult questions easier.

\section{Pendahuluan}

Sekolah Alam Kebun Tumbuh berkiprah di dunia pendidikan dengan cita-cita membangun tunastunas bangsa menjadi berakhlak mulia, cerdas, dengan berpegang teguh pada Al Quran dan Sunnah. Visi Sekolah Alam Kebun Tumbuh adalah menjadi model sekolah alam berkarakter Islam kebanggaan bangsa. Sedangkan misi Sekolah Alam Kebun Tumbuh adalah membentuk pribadi berkarakter cerdas, tangguh, dan berakhlak Islami; mengembangkan pendidikan yang berpedoman pada Alquran dan Assunah; menyediakan sarana prasarana yang efektif dan efisien dalam mendukung kegiatan pembelajaran; menciptakan lingkungan sekolah yang solid, nyaman, dan harmonis; dan menjalin sinergi dengan mitra belajar dan instansi terkait. Nilai yang ditekankan adalah intergritas, profesional, sinergi, kreatif, dan tangguh. Konsep pendidikan mulai dari guru berkualitas sebagai fasilitator dan teladan dalam proses pembentukan akhlak anak, tahfidz hafalan Alquran minimal 2 juz untuk SD, buku sebagai gerbang dan khazanah ilmu pengetahuan, outbond sebagai sarana pembentukkan jiwa kepemimpinan, dan alam semesta sebagai laboratorium tanpa batas. 
Sekolah Alam Kebun Tumbuh menggunakan kurikulum Kemdikbud dan kurikulum akhlak Islami dengan orientasi optimal kepada pembentukan karakter anak. Metode pengintegrasian kurikulum Kemdikbud dengan alam dan budaya melalui model spider web. Spider Web (model jaring laba-laba) adalah pembelajaran terpadu yang menggunakan pendekatan tematik (Ramdhany, 2020). Model ini mengacu pada konsep pengalaman yang terstruktur untuk menjalankan konsep pendidikan berbasis pada alam, budaya, dan pemanfaatan barang bekas. Konsep tersebut memiliki konsep berbeda dengan sekolah pada umumnya. Sementara itu, pengembangan kemandirian anak dapat dilihat melalui materi enterpreneurship dalam bidang bioteknologi, teknologi informasi komunikasi, retail, dan distribution.

Salah satu pengembangan kemandirian dalam bidang teknologi informasi komunikasi yaitu dengan memanfaatkan YouTube yang dimanfaatkan sebagai media pembelajaran bahasa Indonesia dengan studi kasus Sekolah Alam Kebun Tumbuh SD Kelas 1 SD dengan topik cerita rakyat dari Lampung. Sebelumnya, cerita rakyat dibacakan oleh guru. Pada kenyataanya, tidak semua guru pandai membacakan cerita. Jika guru pandai membacakan cerita, siswa akan tertarik, tetapi jika guru tidak pandai membaca cerita, siswa cenderung akan lebih mudah bosan. Hal tersebut menjadi permasalahan dan berpengaruh terhadap pemahaman siswa dalam menjawab pertanyaan. Seharusnya siswa mampu berpikir dan memahami cerita rakyat tanpa harus dipengaruhi oleh kemampuan guru dalam membacakan cerita. Selain itu, menurut Pribadi (2017) guru perlu memilih media yang tepat yang dapat digunakan untuk memfasilitasi siswa dalam memperoleh pengetahuan, keterampilan, dan sikap yang diperlukan.

Pemanfaatan YouTube sebagai media pembelajaran pernah diteliti oleh Lestari (2017) dalam Seminar Nasional Kedua Pendidikan Berkemajuan dan Menggembirakan dengan judul "Penggunaan YouTube sebagai media pembelajaran bahasa Inggris". Hasil penelitian tersebut menunjukkan bahwa video yang ada digunakan sebagai salah satu media pembelajaran. Penelitian tersebut tidak mengkaitkan dengan kemampuan berpikir. Penelitian tentang pemanfaatan YouTube lain yaitu penelitian berjudul "Pemanfaatan Sosial Media YouTube Sebagai Media Pembelajaran bahasa Indonesia di Perguruan Tinggi" oleh Kamhar \& Lestari (2019) yang dimuat dalam Jurnal Inteligensi: Jurnal Ilmu Pendidikan. Penelitian ini membahas YouTube sebagai media ajar yang dekat dengan kehidupan sehari-hari peserta didik. Penulis mengungkapkan bahwa kurangnya kreativitas metode dan media ajar membuat peserta didik jenuh dalam mengikuti proses belajar-mengajar. Penelitian ini tidak mengaitkan dengan kemampuan berpikir.

Penelitian mengenai kemampuan berpikir pernah diteliti oleh Wulandari, Marwadi, \& Wardani (2019) dengan judul "Peningkatan Keterampilan Berpikir Kreatif Siswa Kelas 5 Menggunakan Model Mind Mapping" yang dimuat dalam Jurnal Ilmiah Sekolah Dasar. Hasil penelitian ini menunjukkan adanya peningkatan keterampilan berpikir kreatif siswa dengan menggunakan model mind mapping. Penelitian lain yang senada oleh Farida, Agustini, \& Wakhyudin (2017) berjudul "Efektivitas Model Pembelajran Scramble Berbasis Kontekstual Terhadap Kemampuan Berpikir Kritis IPS Siswa Kelas III SD Negeri Kebondalem 01 Batang". Penelitian ini membahas penerapan pembelajaran scramble berbasis kontekstual membutuhkan manajemen waktu dan pengelolaan kelas yang baik sehingga diperlukan perencanan pembelajaran yang tepat dan matang. Selain itu, pembelajaran ini membutuhkan guru yang berwawasan luas agar dapat memfasilitasi siswa. Penelitian mengenai kemampuan berpikir kritis lainnya yaitu "Penerapan Model Pembelajaran Cooperative Tipe TAI (Team Assisted Individualization) untuk Meningkatkan Hasil Belajar dan Kemampuan Berpikir Kritis Matematika” oleh Wijayanti, Relmasira, \& Juneau (2018) yang dimuat dalam Jurnal Ilmiah Sekolah Dasar. Hasil penelitian tersebut menunjukkan hasil belajar siswa dalam kategori tidak tuntas mengalami penurunan. Pembahasan ketiga penelitian tersebut tidak sampai membahas kemampuan berpikir tingkat tinggi.

Penelitian ini bertujuan untuk memaparkan pemanfaatan YouYube sebagai media pembelajaran bahasa Indonesia dengan studi kasus Sekolah Alam Kebun Tumbuh SD Kelas 1 SD, memaparkan YouTube sebagai stimulus sebelum pemberian soal HOTS, dan memaparkan pemanfaatan YouTube terhadap kemampuan berpikir siswa. Keunggulan penelitian ini melengkapi penelitian sebelumnya yang tidak mengaitkan dengan kemampuan berpikir tingkat tinggi.

Pemanfaatan YouTube sebagai media pembelajaran membantu ketersampaian pesan. Menurut Snelson (2011), YouTube adalah salah satu layanan berbagi video di internet yang paling popular saat ini. YouTube sebagai sebuah situs web video sharing (berbagi video) yang memungkinkan para pengguna menggunggah, mencari video, menonton, diskusi/tanya jawab dan berbagi klip video secara gratis. Videovideo-video tersebut adalah video klip, film, TV, serta video buatan para pengguna. YouTube menjadi situs online video provider paling dominan di dunia dan tidak membatasi durasi untuk mengunggah video. Keunggulan lain, YouTube menawarkan layanan gratis khususnya untuk menikmati dan mengakses videovideo yang masuk dalam sistemnya. Untuk mengakses video pengguna tidak perlu memiliki akun premium atau membayar sejumlah uang dalam skala waktu tertentu. Pengguna dapat mengakses videovideo tersebut secara gratis. Pengguna YouTube dapat mengunduh beberapa video dan setelah berhasil 
terunduh, video dapat disimpan di gadget masing-masing untuk dinikmati kapan tanpa menggunakan sambungan internet.

YouTube digunakan sebagai media pembelajaran karena merupakan salah satu media yang dekat dengan kehidupan siswa sehari-hari. Media pembelajaran menurut Boovee dalam Simamora (2009) mengemukakan bahwa media pembelajaran adalah alat yang digunakan dalam penyampaian dalam proses pembelajaran. Selaras dengan pendapat itu, Arsyad (2017) mendefinisikan media pembelajaran adalah media yang membawa pesan-pesan atau informasi yang bertujuan instruksional atau mengandung maksud-maksud pengajaran. Dalam hal ini, YouTube sebagai media untuk menyampaikan materi pengajaran berupa cerita rakyat.

YouTube sebagai media pembelajaran mempengaruhi kemampuan berpikir siswa. Kemampuan berpikir tingkat tinggi (HOTS) diharapkan oleh pemerintah. Kompetensi tersebut yaitu berpikir kritis (critical thinking), kreatif dan inovasi (creative and innovative), kemampuan berkomunikasi (communication skill), kemampuan bekerja sama (collaboration) dan kepercayaan diri (confidence). Lima hal tersebut menjadi target karakter peserta didik menyusul masih rendahnya peringkat Programme for International Student Assessment (PISA) dan Trends in International Mathematics and Science Study (TIMSS) dibandingkan dengan negara lain (Ariyana, Pudjiastuti, Bestary, \& Zamroni, 2018).

Kemampuan berpikir tingkat tinggi adalah proses berpikir yang mengharuskan siswa untuk memanipulasi informasi yang ada dan ide-ide dengan cara tertentu yang memberikan mereka pengertian dan implikasi baru (Gunawan, 2003). Rosnawati (2009) menjelaskan kemampuan berpikir tingkat tinggi terjadi ketika seseorang mengaitkan informasi yang baru diterima dengan informasi yang sudah tersimpan di dalam ingatannya, kemudian menghubung-hubungkannya dan atau menata ulang serta mengembangkan informasi tersebut sehingga tercapai suatu tujuan ataupun suatu penyelesaian dari suatu keadaan yang sulit dipecahkan.

Menurut Brookhart (2010, p. 29) dalam Kurniati, Harimukti, \& Jamil (2016), kemampuan berpikir tingkat tinggi (HOTS) meliputi kemampuan logika dan penalaran (logic and reasoning), analisis (analysis), evaluasi (evaluation), kreasi (creation), pemecahan masalah (problem solving), dan pengambilan keputusan (judgement). Keterampilan berpikir tingkat tinggi adalah keterampilan yang melibatkan level kognitif tinggi dalam taksonomi Bloom. Taksonomi kognitif Bloom terdiri atas enam level yaitu pengetahuan, pemahaman, aplikasi, analisis, sintesis, dan evaluasi. Keenam level kogntif ini kemudian direvisi oleh Anderson \& Krathwohl (2001) menjadi mengingat (remembering), memahami (understanding), dan menerapkan (applying), menganalisis (analysing), mengevaluasi (evaluating), dan mencipta (creating). Level satu merupakan keterampilan tingkat rendah, level dua dan tiga merupakan keterampilan tingkat sedang, dan level empat sampai enam merupakan keterampilan tingkat tinggi.

Keterampilan berpikir tingkat tinggi sebagai pemecahan masalah diperlukan dalam proses pembelajaran karena pembelajaran yang dirancang berorientasi pada keterampilan tingkat tinggi tidak dapat dipisahkan dari kombinasi keterampilan berpikir dan keterampilan kreativitas untuk pemecahan soal. Kemampuan berpikir tinggi diukur dari jawaban soal yang sudah disesuaikan dengan Taksonomi Bloom.

Penulisan soal HOTS didahului dengan menentukan perilaku yang hendak diukur, merumuskan materi yang dijadikan dasar pertanyaan (stimulus) dalam konteks tertentu sesuai dengan perilaku yang diharapkan. Uraian materi yang akan ditanyakan (yang menuntut penalaran tinggi) tidak selalu tersedia di dalam buku pelajaran. Oleh karena itu, dalam penulisan soal HOTS, dibutuhkan penguasaan materi ajar, keterampilan dalam menulis soal (konstruksi soal) dan kreativitas guru dalam memilih stimulus soal sesuai dengan situasi dan kondisi daerah di sekitar satuan pendidikan.

Langkah-langkah penyusunan soal HOTS yaitu menganalisis kompetensi dasar yang dapat dibuat soal-soal HOTS, Menyusun kisi-kisi soal, Memilih stimulus yang menarik dan kontekstual, Menulis butir pertanyaan sesuai dengan kisi-kisi soal, dan Membuat pedoman penskoran (rubrik) atau kunci jawaban (Widana, 2017). Soal-soal HOTS menggunakan stimulus. Stimulus merupakan dasar untuk membuat pertanyaan. Dalam konteks HOTS, stimulus yang disajikan hendaknya bersifat kontekstual dan menarik. Stimulus juga dapat diangkat dari permasalahan-permasalahan yang ada di lingkungan sekitar satuan pendidikan, keunggulan di daerah tertentu (Widana, 2017).

\section{Metode}

Jenis penelitian ini adalah kualitatif deskriptif. Menurut Bogdan \& Biklen (1992) penelitian kualitatif adalah prosedur penelitian bidang sosial, budaya, dan filssafat yang menghasilkan data deskriptif berupa kata-kata atau catatan-catatan yang berhubungan dengan makna, nilai serta pengertian. Senada dengan itu, Moleong (2006) mengatakan bahwa penelitian kualitatif merupakan prosedur penelitian yang menghasilkan data kualitatif berupa kata-kata tertulis maupun lisan dari perilaku orang- 
orang yang diamati. Sementara itu, penelitian deskriptif menurut Hamdi \& Bahruddin (2014) adalah suatu metode penelitian yang ditujukan untuk menggambarkan fenomena-fenomena yang ada, yang berlangsung pada saat ini atau saat lampau. Menurut Sukmadinata (2010) bahwa metode deskriptif mengkaji bentuk aktivitas, karakteristik, perubahan hubungan, persamaan dan perbedaannya dengan fenomena yang lain. Sementara itu, menurut Silalahi (2009), penelitian kualitatif merupakan suatu proses penyelidikan untuk memahami masalah sosial berdasarkan pada penciptaan gambaran holistik lengkap yang dibentuk dengan kata-kata, melaporkan pandangan informan secara terperinci, dan disusun dalam sebuah latar alamiah.

John Creswell (2008) dalam Raco (2010) menyajikan tahapan dalam penelitian kualitatif yang antara lain sebagai berikut : 1) Tahapan pertama dimulai dengan identifikasi masalah yang menjadi sasaran dalam penelitian. 2) Tahapan kedua yang merupakan kelanjutan dari tahapan sebelumnya yaitu pembahasan/penelusuran kepustakaan. 3) Tahapan ketiga yaitu menentukan maksud dan tujuan dari penelitian. 4) Tahapan keempat berpusat pada pengumpulan data. Pada tahapan ini menyangkut pula pemilihan dan penentuan calon partisipan yang potensial. 5) Tahapan kelima adalah analisis dan penafsiran data. Dan 6) Tahapan terahir pelaporan

Dalam penelitian ini keenam tahapan tersebut telah diterapkan dan subjek penelitian berupa populasi siswa kelas 1 SD Sekolah Alam Kebun Tumbuh Depok Jawa Barat. Sampel penelitian ini yaitu siswa kelas 1 SD yang mengikuti pelajaran Bahasa Indonesia dengan jumlah 24 siswa terdiri dari kelas kurma 13 orang dan kelas zaitun 11 orang. Pengumpulan data dilakukan dengan metode observasi dan penggunaan tes. Metode observasi menurut Arikunto (2013) adalah suatu usaha sadar untuk mengumpulkan data yang dilakukan secara sistematis, dengan prosedur terstandar. Pengumpulan data yang dilakukan dengan mengetahui kondisi siswa di kelas, wawancara untuk memperkuat jawaban siswa dan dokumentasi untuk memperoleh data tentang profil sekolah, identitas siswa serta hasil penelitian. Selain itu, metode yang digunakan adalah dengan menggunakan hasil tes.

Dalam suatu penelitian biasanya digunakan lebih dari satu instrumen Arikunto (2013). Instrumen penelitian ini berupa lembar observasi dan lembar soal dengan bentuk pilihan ganda. Validasi penelitian diuji dengan validitas eksternal. Validitas eksternal bermakna data yang dihasilkan dari instrumen tersebut sesuai dengan data atau informasi lain yang mengenai variabel penelitian yang dimaksud Arikunto (2013). Dalam hal ini, hasil tes mempunyai arah korelasi dengan kondisi siswa di kelas.

Lembar soal yang diujikan kepada siswa dalam penelitian ini disusun berdasarkan tingkat proses kognitif Taksonomi Bloom revisi Anderson dan Krathwohl tahun 2010. Materi yang digunakan adalah topik cerita rakyat dari daerah Lampung yang berupa video dari YouTube. Cerita rakyat tersebut berfungsi sebagai stimulus. Pemanfaatan stimulus mempermudah siswa mengerjakan soal yang tersedia (Qostantia, 2017). Kemudian siswa diminta mengerjakan soal dari tingkat mudah (low order thinking skill/LOTS), sedang (middle order thinking skill/MOTS), dan sulit (high order thinking skill/HOTS). Soal yang diujikan berjumlah 15 soal pilihan ganda meliputi LOTS 5 soal, MOTS 5 soal, dan HOTS 5 soal dengan materi mendengarkan cerita rakyat dari daerah Lampung. Soal pilihan ganda terdiri dari pokok soal (stem) dan pilihan jawaban (option) yang terdiri atas kunci jawaban dan pengecoh (distractor). Pengecoh merupakan jawaban yang tidak benar, namun memungkinkan siswa terkecoh untuk memilihnya apabila tidak menguasai materinya dengan baik. Jawaban yang diharapkan (kunci jawaban) umumnya tidak termuat eksplisit dalam stimulus. Jawaban yang benar diberikan skor 1 dan jawaban yang salah diberikan skor 0 .

Muhajir (1998) mengemukakan pengertian analisis data sebagai upaya mencari dan menata secara sistematis catatan hasil observasi, wawancara, dan lainnya untuk meningkatkan pemahaman peneliti tentang kasus yang diteliti dan menyajikannya sebagai temuan bagi orang lain. Sedangkan untuk meningkatkan pemahaman tersebut analisis perlu dilanjutkan dengan berupaya mencari makna. Kemudian Bogdan dalam Sugiono (2007) berpendapat "Data analysis is the process of systematically searching and arranging the interview transcripts, fieldnotes, and other materials that you accumulate to increase your own understanding of them and to enable you to present what you have discovered to others". Dengan dua pendapat tadi, penganalisisan data dalam penelitian ini dimulai dengan pengumpulan data terlebih dahulu. Lalu dilakukan dengan uji pada kemampuan berpikir siswa dari dari tingkat mudah (low order thinking skill), sedang (middle order thinking skill), dan sulit (high order thinking skill). Teknik analisis data penelitian dilakukan 3 tahap kegiatan yaitu 1) tahap mencatat hasil wawancara dan observasi serta mengumpulkan data dokumentasi dari berbagai sumber terkait dengan tingkat keterampilam berpikir siswa dalam menyelesaikan soal, 2) penyajian data yaitu pengumpulan informasi hasil penelitian, dan 3) penarikan kesimpulan.

\section{Hasil dan pembahasan}


Penelitian mengenai Kemampuan Berpikir Tingkat Tinggi dalam Pemanfaatan YouTube sebagai Media Pembelajaran Bahasa Indonesia menunjukkan bahwa youtube dapat dimanfaatkan sebagai media pembelajaran bahasa Indonesia. Dari hasil wawancara dengan pertanyaan "Siswa lebih memilih memahami cerita rakyat dari daerah Lampung dengan menggunakan YouTube atau diceritakan guru". Siswa menjawab lebih banyak "setuju dengan YouTube" yaitu sebanyak 19 siswa atau 79,16\%. Kemudian, dengan pertanyaan "Apakah siswa merasa bosan atau tidak (lebih menarik dengan YouTube)?". Hasilnya siswa menjawab “lebih menarik YouTube” lebih banyak yaitu 21 siswa atau 88,8\%.

Melalui YouTube berisi video mengenai cerita rakyat dari daerah Lampung mempunyai beberapa manfaat. Manfaat penggunaan video yaitu menayangkan gambar bergerak, memperlihatkan objek, tempat dan peristiwa secara komprehensif sehingga membuat lebih menarik bagi siswa. Siswa dapat mengobservasi kejadian dan merekam kejadian pada media YouTube karena unsur warna, suara, dan gerak mampu membuat karakter lebih hidup sehingga memperkuat pemahaman siswa. Siswa juga dapat dengan mudah melihat proses dan alur cerita rakyat dari daerah Lampung. Video juga merupakan sarana observasi yang aman, sekolah alam sebagian kegiatan belajar mengajar secara outdoor sehingga video ini menjadi salah satu sisi penyeimbang pembelajaran di dalam kelas. Video sebagai sarana untuk mempelajari pengetahuan dan keterampilan khususnya mengenai cerita rakyat dari daerah Lampung. Video memperlihatkan contoh sikap dan tindakan yang dapat dipelajari. Dalam cerita daerah Lampung, Aminah sebagai tokoh utama yang mempunyai sikap cerdik dan dengan tindakannya yang berani berhasil menangkap buaya perompak. Video mendorong munculnya apresiasi atau penghayatan terhadap seni dan budaya dalam hal ini budaya masyarakat Lampung yang berlayar dan berdagang. Video menciptakan kesamaan pengalaman dan persepsi bagi siswa tentang cerita rakyat dari daerah Lampung. Jadi dengan penggunaan video YouTube dapat menarik perhatian siswa daripada bergantung pada guru yang membacakan cerita. Pada kenyataannya, tidak semua guru pandai membacakan cerita rakyat. Selain itu, siswa dapat dengan mudah memperoleh informasi mengenai cerita rakyat dari daerah Lampung. Siswa dan guru juga dapat menggunakan video YouTube dengan berulang-ulang jika dirasa memerlukan pemutaran ulang. Oleh karena itu, Video YouTube mengatasi rasa bosan, meningkatkan minat belajar dan motivasi siswa dalam belajar.

Soal kemampuan berpikir tingkat tinggi umumnya menggunakan stimulus yang bersumber dari situasi yang nyata yaitu berisi video mengenai cerita rakyat dari daerah Lampung. Pada hasil wawancara dengan pertanyaan "Siswa lebih mudah memahami cerita dengan YouTube atau dengan cerita dari guru?". Siswa menjawab lebih banyak "lebih mudah dengan YouTube" yaitu sebanyak 20 siswa atau 83,3\%. Hal tersebut menunjukkan pemanfaatan stimulus untuk mempermudah siswa mengerjakan soal yang telah tersedia. Stimulus sebagai dasar untuk membuat pertanyaan. Dalam hal ini video tersebut bersifat kontekstual dan menarik bersumber dari budaya masyarakat Lampung. Dalam cerita tersebut terdapat permasalahan-permasalahan di lingkungan masyarakat Lampung yang berdagang dan berlayar. Sebagai contoh, cara mengatasi buaya perompak agar tidak merompak pedagang. Dengan permasalahan demikian, menambah kreativitas dalam menulis soal HOTS.

Pada ranah kognitif, setelah siswa menyimak cerita rakyat melalui YouTube, pemahaman siswa diuji dari soal yang diberikan. Siswa diberikan soal pilihan ganda yang berjumlah 15 kepada 24 orang siswa. Pemilihan bentuk pilihan ganda disesuaikan dengan siswa yang masih duduk di SD kelas 1 . Hal tersebut agar informasi lebih rinci dan menyeluruh tentang kemampuan siswa pada tingkat dasar yang belum mahir menuliskan kosakata. Tujuannya agar penilaian yang dilakukan menggambarkan kemampuan peserta didik sesuai keadaan sesungguhnya.

Soal pilihan ganda terdiri dari pokok soal dan pilihan jawaban. Pilihan jawaban terdiri atas kunci jawaban dan jawaban pengecoh. Kunci jawaban adalah jawaban yang benar namun memungkinkan seseorang terkecoh untuk memilihnya apabila tidak menguasai materi pelajaran dengan baik. Kunci jawaban tidak termuat secara eksplisit dalam stimulus. Siswa diminta menemukan jawaban soal yang terkait dengan stimulus menggunakan konsep-konsep pengetahuan yang dimiliki serta menggunakan logika/penalaran. Jawaban yang benar diberikan skor 1 dan jawaban yang salah diberikan skor 0 .

Soal yang diberikan dalam penelitian ini meliputi soal mudah (low order thinking skill/LOTS) yang terdiri dari 5 soal, soal sedang (middle order thinking skill/MOTS) yang terdiri dari 5 soal, dan soal sulit (high order thinking skill/HOTS) yang terdiri dari 5 soal. Pada tabel 01 berikut ini, akan dijabarkan nilai hasil tes siswa SD kelas 1 Sekolah Alam Kebun Tumbuh.

Tabel 01. Nilai Tes Siswa SD kelas 1 Sekolah Alam Kebun Tumbuh 


\begin{tabular}{ccccc}
\hline No & Ketrangan & Nilai LOTS & Nilai MOTS & Nilai HOST \\
\hline 1 & Nilai tertinggi & 10 & 10 & 10 \\
2 & Nilai Terendah & 6 & 4 & 2 \\
3 & Rata-rata & 9,2 & 7,75 & 7,6 \\
4 & Siswa Tuntas & 24 Siswa & 22 Siswa & 22 Siswa \\
\hline
\end{tabular}

Berdasarkan tabel 01, rata-rata siswa pada soal LOTS mencapai 9,2, rata-rata siswa pada soal mencapai MOTS 7,75, rata-rata siswa pada soal HOTS 7,6. Hal tersebut menunjukkan jarak rata-rata antara soal MOTS dan HOTS tidak terlalu jauh, hanya terpaut 0,15 . Nilai tertinggi LOTS, MOTS, dan HOTS sama yaitu 10 dan nilai terendah LOTS, MOTS, dan HOTS yaitu 6,4,2. Pada nilai LOTS semua siswa mendapat nilai tuntas, pada MOTS dan HOTS sama yaitu 22 siswa yang mendapat nilai tuntas dan ada 2 siswa yang belum tuntas. Hal tersebut menunjukkan bahwa YouTube memudahkan siswa dalam mengerjakan soal LOTS, MOTS, dan HOTS yang terlihat dari perbedaan antara MOTS dan HOTS tidak terlalu jauh.

Pemanfaatan YouTube sebagai media pembelajaran membantu ketersampaian pesan. Menurut Snelson tahun 2011, YouTube adalah salah satu layanan berbagi video di internet yang paling popular saat ini. YouTube sebagai sebuah situs web video sharing (berbagi video) yang memungkinkan para pengguna menggunggah, mencari video, menonton, diskusi/tanya jawab dan berbagi klip video secara gratis. Videovideo-video tersebut adalah video klip, film, TV, serta video buatan para pengguna. YouTube menjadi situs online video provider paling dominan di dunia dan tidak membatasi durasi untuk mengunggah video. Keunggulan lain, YouTube menawarkan layanan gratis khususnya untuk menikmati dan mengakses videovideo yang masuk dalam sistemnya. Untuk mengakses video pengguna tidak perlu memiliki akun premium atau membayar sejumlah uang dalam skala waktu tertentu. Pengguna dapat mengakses videovideo tersebut secara gratis. Pengguna YouTube dapat mengunduh beberapa video dan setelah berhasil terunduh, video dapat disimpan di gadget masing-masing untuk dinikmati kapan tanpa menggunakan sambungan internet.

YouTube digunakan sebagai media pembelajaran karena merupakan salah satu media yang dekat dengan kehidupan siswa sehari-hari. Media pembelajaran menurut Boovee dalam Simamora (2009) mengemukakan bahwa media pembelajaran adalah alat yang digunakan dalam penyampaian dalam proses pembelajaran. Selaras dengan pendapat itu, Arsyad (2017) mendefinisikan media pembelajaran adalah media yang membawa pesan-pesan atau informasi yang bertujuan instruksional atau mengandung maksud-maksud pengajaran. Dalam hal ini, YouTube sebagai media untuk menyampaikan materi pengajaran berupa cerita rakyat.

YouTube sebagai media pembelajaran mempengaruhi kemampuan berpikir siswa. Kemampuan berpikir tingkat tinggi (HOTS) diharapkan oleh pemerintah. Kompetensi tersebut yaitu berpikir kritis (critical thinking), kreatif dan inovasi (creative and innovative), kemampuan berkomunikasi (communication skill), kemampuan bekerja sama (collaboration) dan kepercayaan diri (confidence). Lima hal tersebut menjadi target karakter peserta didik menyusul masih rendahnya peringkat Programme for International Student Assessment (PISA) dan Trends in International Mathematics and Science Study (TIMSS) dibandingkan dengan negara lain (Ariyana et al., 2018).

Kemampuan berpikir tingkat tinggi adalah proses berpikir yang mengharuskan siswa untuk memanipulasi informasi yang ada dan ide-ide dengan cara tertentu yang memberikan mereka pengertian dan implikasi baru (Gunawan, 2003). Rosnawati (2009) menjelaskan kemampuan berpikir tingkat tinggi terjadi ketika seseorang mengaitkan informasi yang baru diterima dengan informasi yang sudah tersimpan di dalam ingatannya, kemudian menghubung-hubungkannya dan atau menata ulang serta mengembangkan informasi tersebut sehingga tercapai suatu tujuan ataupun suatu penyelesaian dari suatu keadaan yang sulit dipecahkan.

\section{Simpulan dan saran}

Penelitian ini diharapkan memberikan sumbangan nyata terhadap para pengajar di kelas sehingga memanfaatkan video YouTube sebagai media pembelajaran. Selain itu, video YouTube membuat pembelajararan menarik. Video YouTube juga meningkatkan minat membaca siswa dan meningkatkan ide. Dengan ide siswa secara langsung merangsang kemampuan berpikir siswa, terutama kemampuan berpikir tingkat tinggi.

Kemampuan berpikir tingkat tinggi bertujuan menjadi bekal siswa menyongsong era global, kemajuan teknologi informasi, konvergensi ilmu dan teknologi sebagai imbas teknosains, serta bangkitnya industri kreatif di masa depan. Siswa yang memiliki kemampuan berpikir tinggi akan lebih mampu 
menginterpretasikan dan meninjau informasi-informasi yang ada serta mampu menggunakan informasi tersebut untuk memecahkan masalah yang sedang dihadapi.

Berdasarkan hasil penelitian ini, dapat disarankan beberapa hal kepada: 1) Guru, guru diharapkan lebih kreatif dalam memilih media pembelajaran sehingga dapat meningkatkan hasil belajar dan motivasi belajar siswa. 2) Kepala sekolah, kepala sekolah diharapkan lebih memberikan kesempatan kepada guru untuk berkusi melalui FGD untuk meningkatkan kompetensi guru. 3) Peneliti sejenis, peneliti sejenis kiranya dapat menggunakan hasil penelitian ini sebagai referensi untuk mengembangkan media pembelajaran sehingga mampu mengatasi masalah-masalah dalam pembelajaran.

\section{Daftar Rujukan}

Anderson, L. W., \& Krathwohl, D. R. (2001). Taxonomy for Learning, Teaching and Assessing: A Revision of Bloom's Taxonomy of Educational Objectives. New York: Longman.

Arikunto, S. (2013). Prosedur Penelitian Suatu Pendekatan Praktik. Jakarta: Rineka Cipta.

Ariyana, Y., Pudjiastuti, A., Bestary, R., \& Zamroni. (2018). Buku Pegangan Pembelajaran Berorientasi Pada Keterampilan Berpikir Tingkat Tinggi. Jakarta: Direktorat Jenderal Guru dan Tenaga Kependidikan, Kemnetrian Pendidikan dan Kebudayaan.

Arsyad, A. (2017). Media Pembelajaran. Jakarta: Rajawali Pers.

Bogdan, R. C., \& Biklen, S. K. (1992). Qualitative Research for Education: An Introduction to Theory and Method. Boston: Allyn and Bacon.

Farida, U., Agustini, F., \& Wakhyudin, H. (2017). Efektivitas Model Pembelajaran Scramble Berbasis Kontekstual Terhadap Kemampuan Berpikir Kritis IPS Siswa Kelas III SD Negeri Kebondalem 01 Batang. Jurnal Ilmiah Sekolah Dasar, 1(3), 192-199.

Gunawan, A. W. (2003). Genius Learning Strategy: Petunjuk Praktis untuk Menerapkan Accelerated Learning. Jakarta: PT Gramedia Pustaka Utama.

Hamdi, A. S., \& Bahruddin, E. (2014). Metode Penelitian Kuantitatif Aplikasi Dalam Pendidikan. Yogyakarta: Deepublish.

Kamhar, M. Y., \& Lestari, E. (2019). Pemanfaat Sosial Media Youtube Sebagai Media Pembelajaran Bahasa Indonesia DI Perguruan Tinggi. Inteligensi: Jurnal Ilmu Pendidikan, 1(2).

Kurniati, D., Harimukti, R., \& Jamil, N. A. (2016). Kemampuan Berpikir Tingkat Tinggi Siswa SMP di Kabupaten Jember dalam Menyelesaikan Soal Berstandar Pisa. Jurnal Penelitian Dan Evaluasi Pendidikan, 20(2), 142-155.

Lestari, R. (2017). Pengunaan Youtube sebagai Media Pembelajaran Bahasa Inggris. The Second Progressive and Fun Education Seminar, 607-612.

Moleong, L. J. (2006). Metode Penelitian Kualitatif. Bandung: PT Remaja Rosdakarya.

Muhajir, N. (1998). Metodologi Penelitian Kualitatif. Bandung: PT Remaja Rosdakarya.

Pribadi, B. A. (2017). Media dan Teknologi dalam Pembelajaran. Jakarta: Kencana.

Qostantia, L. N. (2017). Bahan Ajar Menulis Cerita Fabel dengan Stimulus Film Finding Nemo. Jurnal Pendidikan: Teori, Penelitian, Dan Pengembangan. Pascasarjana Universitas Negeri Malang, 2(3).

Raco, J. R. (2010). Metode Penelitian Kualitatif Jenis, Karakteristik, dan Keunggulannya. Jakarta: PT Gramedia Widiasarana Indonesia.

Ramdhany, W. E. (2020). Model Pengembangan Kurikulum Sekolah Alam ( Studi Deskripsi di Sekolah Dasar Alam Kebun Tumbuh Bojongsari Sawangan Depok Jawa Barat ) NPM Disusun Oleh:: Wahyu Eko Ramdhany Universitas Muhammadiyah JAKARTA 1441 H / 2020 M. Universitas Muhammadiyah.

Rosnawati, R. (2009). Enam Tahapan Aktivitas Dalam Pembelajaran Matematika Untuk Mendayagunakan Berpikir Tingkat Tinggi Siswa. 1-12.

Silalahi, U. (2009). Metode Penelitian Sosial. Bandung: Refika Aditama.

Simamora, R. (2009). Pendidikan dalam Keperawatan. Bandung: EGC.

Snelson, C. (2011). YouTube across the Disciplines: A Review of the Literature. Merlot Journal of Online 
Learning and Teaching, 7(1), 159-169.

Sugiono. (2007). Metode Penelitian Bisnis. Bandung: Alfabeta.

Sukmadinata, N. S. (2010). Metode Penelitian Pendidikan. Bandung: Remaja Rosdakarya.

Widana, I. W. (2017). Penyusunan Soal Higher Order Thinking Skill (HOTS). Jakarta: Departemen Pendidikan dan Kebudayaan.

Wijayanti, R. R., Relmasira, S. C., \& Juneau, J. L. (2018). Penerapan Model Pembelajaran Cooperative Tipe TAI ( Team Assisted Individualization ) untuk Meningkatkan Hasil Belajar dan Kemampuan Berpikir Kritis Matematika. Jurnal Ilmiah Sekolah Dasar, 2(4), 412-419.

Wulandari, F. A., Marwadi, \& Wardani, K. W. (2019). Peningkatan Keterampilan Berpikir Kreatif Siswa Kelas 5 Menggunakan Model Mind Mapping. Jurnal Ilmiah Sekolah Dasar, 3(1), 10-16. 